\title{
The Morality of Carelessness: The Montclair Typhoid Epidemic of 1894
}

\section{Dan Capriotti}

\begin{abstract}
As Montclair began to develop from a small town into a prosperous suburb in the late $19^{\text {th }}$ Century, an outbreak of typhoid swept through the community, killing as many as fifty people. An investigation uncovered evidence of carelessness if not outright incompetence, but no officials were held accountable for their actions and inactions.
\end{abstract}

Stroll through an old cemetery in any small town and you will sometimes notice concentrations of dates in the winter months, when pneumonia and other diseases took their yearly toll among the old, the infirm, or the very young. In many places you may notice a cluster associated with well-known disease outbreaks, most notably from 1918 and 1919, when influenza raged around the world in wave after wave, killing hundreds of thousands across the United States alone.

Walk in an old graveyard in Montclair and you might notice an unusual number of deaths clustered in the spring of 1894. Throughout April and May of that year as many as fifty residents of the prosperous leafy suburb of 10,000 were swept away by an epidemic outbreak of typhoid fever that took young as well as old; rich as well as poor; Presbyterians, Congregationalists, and Baptists. It is a sad story of small town loss and tragedy; but most distressing, perhaps, and maybe instructive, is that it was a completely unnecessary conflagration, a preventable tragedy.

Montclair in 1894 was atop a wave of prosperity and modernity. Founded by Dutch farmers who had migrated westward from Newark in the eighteenth century, it had retained its rural character through the middle of the nineteenth. But the coming of the railroad in the 1870s changed all that: suddenly businessmen, financiers, bankers, and lawyers were able to commute from the suburbs to New York City in just little over an hour. As today, cities were then seen as acceptable places to work and do business but less than desirable - unhealthy and dangerous places - to live and raise a family. Increasingly, those who could afford to move out to "the country," did so. ${ }^{1}$ 
The rural, farming landscape was transformed in a single generation. In the three decades from 1860 to 1890 Montclair's population jumped from 2,000 to 10,000, and the value of the land in town increased by several-fold. ${ }^{2}$ Stolid banks and modern shops were constructed along the main street, now known as Bloomfield Avenue. Where a few old churches had ministered to the generations, a flurry of new congregations were established and new church buildings were erected - many were off-shoots of First Presbyterian Church that had dominated religious life in Montclair for more than a century. A Roman Catholic church, Immaculate Conception, was founded to serve more than 500 mostly Irish and German families. New streets were opened by the dozens, others were paved; schools were constructed or expanded; and scores of homes - grand Victorians, modest colonials, and sprawling boardinghouses - were built to shelter those many thousands. Montclair in 1894 was still a place where boys jumped naked into swimming holes, but it was also a modern community about to embrace the twentieth century.

To modern Americans, typhoid seems like a relic of a bygone era, like corsets or kerosene lamps. In fact, until the advent of widespread sewage and drinking water treatment processes in the western world in the 1930s, typhoid was a present if uncommon danger that was fatal often enough to cause real fear whenever it appeared. In the Spanish-American War of 1898, one-fifth of the American soldiers fell ill with typhoid fever, and the disease killed six times as many of them as did battle wounds. As demonstrated by the Englishman William Budd as early as the 1850s, the Salmonella typhii bacterium is passed from person to person through contaminated water and food supplies. ${ }^{3}$ It is, therefore, considered a "disease of civilization": one that occurs when people live in close contact with each other. As such it is most often seen in the bustling cities of the world, but it can be found in any place humans live together, including the American suburbs of the nineteenth century.

The onset of typhoid is characterized by fever, severe headache, and a bronchial cough; other symptoms may include abdominal complaints, including tenderness in the belly, constipation, and diarrhea. Many of these symptoms are common to a number of diseases so, in the time before laboratory analysis, making a diagnosis of typhoid fever 
was sometimes difficult (though typhoid often produces a transient rash, called "rose spots," that usually begins on the abdomen, that can make diagnosis easier). As the course of the disease progresses the symptoms can become severe and torturous: the headache worsens and may involve mental confusion and stupor. The liver and spleen usually become enlarged, which in addition to being quite painful may cause perforation and subsequent infection and sepsis. The bronchitis often flares into life-endangering pneumonia. Left untreated, mortality ranges between 10 and 20 percent, and it is a painful death. In 1894, fifty years before the advent of antibiotics, all cases were essentially untreated; palliative measures were used in an attempt to reduce the suffering, but the disease could not be checked. Doctors and loved ones alike simply waited for the patient to recover... or to die.

Montclair's epidemic of 1894 began in the middle of February, when fever struck sixteen year-old William Dodd Gould, the son a farmer and sometimes dairyman who lived in the neighboring town of Verona. ${ }^{4}$ The boy suffered without medical help for about a week before his father flagged down a passing physician, Dr. John J. Love, who was traveling south along Pompton Turnpike on his way home to Montclair. Dr. Love, a local physician and civic leader, gruff and opinionated but passionate about his commitment to his profession, didn't know the Gould family but agreed to see the suffering boy. Called back to the farm on February 21, Dr. Love finally decided that the case was typhoid and directed that the boy's bedpan no longer be emptied in the privy for fear that it could contaminate the family's drinking water. The privy was directly uphill of the home, he discovered, about sixty-five feet from the well that served as the household's sole water source. Love advised that the contents of the teen's bedpan be buried at a spot further from the well instead. There the matter rested.

About a week later, Dr. Love ran into Charles B. Morris, the local tax assessor and the Secretary of the township's Board of Health. When Love mentioned the case of typhoid at Gould's farm, Morris exclaimed, "Why, that man Gould is a milkman and I take milk from him!" Dr. Love, who was leaving the next day with his family for a twoweek vacation in Florida, urged Morris to alert the Board of Health, and to look into the matter right away. ${ }^{5}$ 
The next day - in addition to stopping his own family's delivery of milk from farmer Gould - Morris told the municipal Health Inspector, Dr. Richard P. Francis, of his conversation with Love, and Dr. Francis visited the Gould farm the next day. The young, Harvard-educated Dr. Francis asked what directions Dr. Love had given, and was satisfied that those instructions were being followed. He also inspected the farmer's milk bottling operation, which was conducted outside the farmhouse's back door at the well. He directed that the washed bottles be completely emptied of water and stood upside down after washing. And finally he told the farmer that he was "on no account to have anything whatever to do with the care of the patient." But he apparently did not consider shuttering the dairy operations. ${ }^{6}$

Such laxity on behalf of a public health official might seem incomprehensible to a modern reader, but it should be remembered that the germ theory of medicine - the understanding that many diseases are caused by microbes and not by "miasmas" or stale air - was relatively new in 1894; pasteurization of milk was decades in the future; even the sterilization of surgical equipment was a brand new concept in the medical field in the 1890s. Still, as noted above, the connection between typhoid fever and contaminated food and water had been well understood since the middle of the nineteenth century; the ninth edition of the Encyclopedia Britannica, published in 1889 and aimed at the general public, contained the straightforward assertion that, "There is abundant evidence that one of the vehicles for the contagion is food, especially milk, which may readily become contaminated with the products of the disease where an outbreak of disease has occurred in a dairy." The intersection of the words "dairy" and "typhoid" should have set off alarm bells in the minds of both Secretary Morris and Health Inspector Francis, but if it did, such a warning was deeply muffled and almost ignored.

Dr. Francis' underwhelming response included the notification - a day later - of George W. McGuire, the State Dairy Commissioner, and the township's official physician, Dr. James S. Brown. Dr. Brown took no action, and though the Dairy Commissioner sent an inspector the next day, March 3rd, this man only examined the state of farmer Gould's dairy herd, and looked into the "quality" of the milk produced, both of which he found to be "excellent." He told Mr. Gould that there was "no danger" 
from continuing to sell his milk. As of this date, the only case of typhoid fever in the vicinity was that of William Gould, who by then was making a full recovery.

The Montclair Board of Health held its regular meeting on March 5, at which the actions of Dr. Francis, who was not present, were reported and briefly discussed. ${ }^{7}$ The visit from the State Dairy Inspector was also mentioned. Assuming that all appropriate measures had been taken, the Board adjourned without taking further action. There was not even a discussion of the matter at the next Board meeting, on March 19th. Mr. Gould continued his daily milk route as before (except that he no longer stopped at the Morris house).

By March 20 another of Gould's sons, Elbert Ward, was diagnosed with typhoid; the eighteen year-old had been ailing for about a week before the formal diagnosis, and was now confined to bed. But Elbert's wasn't the only case that appeared in the third week in March. Dr. Brown stated, "There was a case reported... of typhoid fever on Highland Avenue, and I ascertained that they were drinking Gould's milk." This, one would imagine, was enough for the township's physician to take decisive steps, but the action Dr. Brown took was tentative -- instead of charging up to the Gould farm himself and completely closing down the contaminated dairy, he "suggested" that Dr. Francis "go up there and stop Gould selling milk in Montclair" (emphasis added). A day or two later Dr. Francis did just that, only to find Gould away from home. Instead of issuing instructions to stop milk production, Dr. Francis left a message asking the farmer to call him back the next day. Thus it was March 29 before any municipal official told Gould to stop selling milk, and then only in the town of Montclair (officials later said they weren't sure they had the statutory authority to stop him from selling milk altogether). On March 30, at Dr. Francis' urging, the State Dairy Commissioner finally ordered Gould to stop selling milk.

Though the dairy business was not Gould's main source of income, losing his route in Montclair must have been a blow; he tried, in fact, to save the route - and his reputation in the community - by engaging a neighboring farmer, George Taylor, to serve his customers. Taylor procured his milk supply from his own father's farm, but used 
Gould's bottles and equipment. Apparently, this arrangement didn't satisfy either provider or customers, and after a few days the operation was discontinued altogether.

Meanwhile, a full-fledged typhoid epidemic had emerged in Montclair and surrounding communities, and almost all the cases were in homes that had been supplied by milk from George Gould's farm. The number of cases that were recognized as typhoid in the first week of April varied. On April 16 the New York Times reported that one physician "not a member of the Board of Health said he had a list of sixty-one cases in Montclair, and knew also of three cases in Verona, and seven in Glen Ridge, two townships which adjoin Montclair and, save for the boundary lines laid down by municipal ordinances, are part of the same village." ${ }^{8}$ Another doctor, an official with the township, put the number at "about forty," while a third physician split the difference with specificity, saying that "the whole number of the living and dead who had the disease was fifty-three." Dr. Brown stated a few days later that there were "probably more cases of the fever resulting from the use of tainted milk than had been reported." And some of those afflicted had begun to die. The first fatality was Montclair resident Frederick Roberts, Jr. (in the end the Roberts family suffered five cases of typhoid, though the rest survived). Clifford Hovy, a young African American part-time letter carrier, was also among the first swept away; it was said he was a daily consumer of milk from the Gould dairy. ${ }^{9}$ The family of businessman Seman A. Swenarton was particularly hard-hit; daughters Mary and Julie both passed away in early April, while Mr. Swenarton and two other children were afflicted but survived. Seventeen-year-old Samuel Prescott was also among the early dead, as was 70-year-old Helen Dodge, who lived in one of the community's boarding houses; the infant son of New York City lawyer Charles Noyes also succumbed, though Mr. Noyes' sister Jennie, who lived in the same home, survived.

Ironically, Harding Taylor, the 27-year-old brother of Charles Taylor, who briefly took over the Gould delivery route, was also a typhoid victim. Hardy, a dairyman himself who occasionally purchased part of his supply from George Gould, was initially dismissive of any criticism of Gould's milk, and on one occasion drank some of the disputed product in the presence of his customers as a way of showing them there was nothing wrong with the stuff. Taylor died of typhoid on April $12 .{ }^{10}$ 
The epidemic - and the deaths - continued through mid-April, and it wasn't long before township officials and physicians came in for sharp criticism for their inaction. As the criticism grew these men circled the wagons and tried to present a united front of competence and authority, while working studiously to avoid responsibility. The township's Health Inspector, Dr. Francis, deflected blame to the state, "I considered the State Dairy Commissioner a man competent to deal with the milk trouble, and did not consider any action on our part was necessary," 11 while the State Dairy Commissioner took the opposite tack, "I consider that the health Board of Montclair was doing everything possible to prevent the spread of any diseases from Gould's dairy, and I do not think that any human agency could have stopped the disease sooner." The municipal physician, Dr. Brown, set out a similar line, "...the mere fact of having a case of typhoid - it was not a dead sure thing that the typhoid would get into the milk supply so long as (Gould) was taking the precautions he was taking. There were a good many chances against it." Health Board Secretary Charles Morris stated that his central concern was for a local businessman, "With respect to Gould, my own feeling was that I did not wish publish the case unless it was necessary, as it would ruin his business." Dr. Love, returned from his vacation in Florida, blamed every official who came in contact with the matter after him: "If the distribution of the milk could have been stopped when I reported it, the trouble could not have spread."

But the trouble did spread, and the epidemic raged throughout April and into May. Mrs. A. H. Siegfried, the wife of the advertising manager of the Ladies Home Journal, succumbed in mid-April, as did 35-year-old blacksmith James McDonald. So did Annie and little John Cunningham, the children of James Cunningham of Cherry Street. Newspaper reports name among the dead a Miss Werts, "colored woman, living on Forest Street," and a Miss Webster, a seamstress "who contracted the disease while working for Mrs. Reed" (the newspaper doesn't report how the Reed family fared). ${ }^{12}$ In mid-April, however, official Montclair declared, as if by common agreement, a moratorium on information about the progress of the disease. Indeed, at the April 16 meeting of the Board of Health, Secretary Charles Morris, perhaps in a state of remorse, requested permission to issue a statement about the number of fatalities attributable to the outbreak, but his suggestion was tabled by Board chairman (and long-time Township Committee 
leader) John H. Wilson, who stated that such information was "not important." 13 After this, specific information about how many people had been caught up in the epidemic becomes hard to find, but a New York Times article published on August 8, 1894 (reporting on a possible return of typhoid) stated that the spring epidemic has "swept away nearly fifty...inhabitants."14

Neither the official stonewalling nor attempts to evade responsibility deterred a "Special Commission" that was established under the auspices of the Montclair Club, an influential social club composed of the town's leading citizens. The Commission, which included such local notables as well-known financial journalist Alexander Noyes (whose brother Charles lost his infant son early in the epidemic), Montclair Times publisher A. C. Studer, businessmen Benjamin Strong and Joseph van Vleck, and publisher and literary critic John R. Howard, took testimony from all the participants, and even made a visit to George Gould's farm. Given that the men who conducted the inquiry were investigating their neighbors, colleagues, and fellow club members, their eleven-page report, issued in May, took a polite but definitive position that responsible officials had egregiously erred in not taking swift action as soon as the first case of typhoid emerged:

It was competent for any one, official of non-official, to say, personally or in the public press: There's typhoid at Gould's dairy. Experience has shown that typhoid in a dairy is about as dangerous as an uncovered light in a powder magazine. ... Perhaps in the early days of the epidemic they [health officials] were not as strongly convinced as now of the danger there was in using milk from the Gould dairy, but in the light of subsequent events we think they will agree...that the omission to stop the sale of milk on or about the 1st of March was a serious error, or oversight, by whichever name it may be called. ${ }^{15}$

In the end, no one was ever held responsible. No one was fired or even officially censured. Charles Morris continued in all of his municipal positions. No malpractice was alleged: Drs. Brown and Francis had illustrious and lengthy medical careers. Dr. Love died suddenly three years later of a cerebral hemorrhage, hailed by funeral orators as a healer second only to Hippocrates. Nothing is recorded of the future career of George Gould, except that he died quietly on his farm in 1926. Though George McGuire's 
official title changed several times over the years, he was still overseeing New Jersey's dairy industry well into the 1920s. Though it was entirely avoidable and preventable, no one ever paid any price for the Montclair typhoid epidemic of 1894, except, of course, the victims.

Unofficial condemnation of those involved, however, came from an unlikely source: the local pulpit. The beloved pastor of Montclair's First Congregational Church, Amory Howe Bradford, a titan in the community, spoke with passion on April 16, 1894 in a sermon entitled "The Morality of Carelessness." Speaking not only of the farmer George Gould but also of those entrusted with the public health, the redoubtable Rev. Bradford thundered:

A great crime has been committed, and that, no doubt, simply because someone was careless. No one would intentionally spread such a disease. Who is the criminal? Something is wrong somewhere. The damage done could not have been more deadly if a bomb from a foreign gunboat had been aimed at our hillside and a shell had exploded in our streets!... A man who violates a sanitary law is no more excusable than one who deliberately aims a pistol at his neighbor's head and kills him. ${ }^{16}$

\footnotetext{
${ }^{1}$ Philip Doremus, Reminiscences of Montclair, (1908), accessed 10-26-11 http://www.rootsweb.ancestry.com/ genepool/montnj17.htm .

${ }^{2}$ Henry Whittemore, History of Montclair Township, (The Suburban Publishing Company, New York, 1894).

${ }^{3}$ Robert Moorhead, MD FRACGP, "William Budd and typhoid fever," Journal of the Royal Society of Medicine, 2002 November; 95(11): 561-564.

${ }^{4}$ Special Committee, "Report on the Typhoid Epidemic in Montclair, New Jersey," (The Montclair Club, 1894), 6.

5 Special Committee, "Report," 6.

${ }^{6}$ Special Committee, "Report," 7.

${ }^{7}$ Special Committee, "Report," 8.

8 "Typhoid raging in Montclair," New York Times, April 16, 1894.

9 "More deaths at Montclair," New York Times, April 18, 1894.

10 "Typhoid raging in Montclair," New York Times, April 16, 1894.

11 Special Committee, "Report," 14.

12 “Typhoid raging in Montclair,” New York Times, April 16, 1894.

13 "More deaths at Montclair," New York Times, April 18, 1894.

14 "Montclair again in danger," New York Times, August 8, 1894.

15 Special Committee, "Report," 10.

16 "Blamed by Montclair folk," New York Times, April 17, 1894.
} 